\title{
Arbejdersolidaritet? Selvorganisering og statspolitik
}

\author{
Peter Abrahamson, Mogens Holm og \\ Iver Hornemann Mфller.
}

I artiklen: Socialpolitik mellem selvforvaltning og stat, i dette nummer af bladet, kommenterer Per Jensen nogle problematiseringer af velfærdsstatens udvikling.*

Vi er blevet provokeret af Per Jensens synspunkter og fremsætter vore kommentarer, der dog ikke tekstmæssigt går i detaljer, men omtaler nogle hovedproblemer omkring velfærdsstatens interventioner overfor lønarbejderne.

\section{Statsliggørelsen af arbejdsløsheds- systemet i 1907 og i dag}

Ud fra ønsket om »at give stats- og reformismekritikken jordforbindelse « foretager Per Jensen (P.J.) en sammenligning mellem det danske arbejdsløshedssystem, det såkaldte Genter-system og det centraleuropæiske (og det engelske), det såkaldte helstatslige system. I begge systemer er staten central, men i modsætning til det centraleuropæiske bygger Genter-systemet på fagbevægelsens administration af udbetalinger og dermed på en snæver politisk og $\varnothing$ konomisk forbindelse mellem fagbevægelse og arbejdsløshedsforsikringen.

P.J. argumenterer for Genter-systemet, der blandt andet har »bidraget til, at der i Danmark i 1980'erne findes nogle af de højeste organisationsprocenter i Vesteuropa«. I sin lovprisning af Genter-systemet tager P.J. skridtet videre og rejser det centrale spørgsmål, om arbejderklassen i hvert fald på langt sigt ville have stået stærkere uden statsliggørelse af dens arbejdsløshedskasser. Det mener han ikke og argumenterer her mod Hans Erik Avlund Frandsen m.fl. (1979) og Iver Hornemann Møller (1981), der begge hælder til, at den delvise statsligg ørelse (tilskud og muligheder for kontrol) i 1907 - ikke mindst på baggrund af nedskæringer og repressive foranstaltninger i de følgende årtier i hvert fald på lang sigt har svækket arbejderklassen.

* Det drejer sig om: Peter Abrahamson: Fra velfærdsstat til velfærdssamfund? $i$ Nordisk Forum, nr. 43, vol. 19, nr. 3, 1984, Hans Erik Avlund Frandsen m.fl.: Planøkonomi og folkefront, København 1979, Mogens Holm: Velfærdsstatspolitik og velfærdsstatskritik, $i$ Kurasje nr. 37, 1985 og Iver Hornemann Møller: Klassekamp og sociallovgivning 1850-1970, Socialistiske Økonomers Forlag, 1981. 
Det er et vigtigt spørgsmål, P.J. rejser. Både historisk og aktuelt - og det fortjener en lidt grundigere behandling.

Det mindre interessante spørgsmål om, hvad der ville vare sket, hvis fagbevægelsen i 1907 havde fulgt syndikalisternes råd og afvist statsliggørelsen, skal vi lade ligge. Nu blev statsliggørelsen (efter Genter-systemet) en realitet, og de statslige tilskud gjorde det, som P.J. rigtigt påpeger, herefter muligt for fagforeninger med relativt lave lønninger og høj arbejdsløshed, at oprette A-kasser. Der er næppe tvivl om, at på kort sigt var 1907-loven både en styrkemæssig og velfærdsmæssig gevinst for arbejderklassen. Men gælder det også, når lovgivningen vurderes over en årrække?

Det væsentligste spørgsmål er i denne sammenhæng, om de $\varnothing$ konomiske og politiske strukturer og magtrelationer, der gjaldt i 1907, har ændret sig så lidt i løbet af de 80 år, at statsliggørelse med P.J. stadig kan siges at være en fordel for arbejderklassen.

De talrige historiske, men også næsten dagaktuelle erfaringer omkring stramninger af kontrolbestemmelserne, optagelsesbestemmelserne, udbetalingsreglerne, tilrådighedsreglerne samt ikke mindst nedskæringer i og forringelser af underst $\varnothing$ ttelsens $h \varnothing j-$ de og udbetalingsperiode taler deres klare sprog om statsliggørelsen negative sider! Hertil kommer så, at finansieringssiden ser helt anderledes ud i 1986 end i 1907, hvor lønarbejderne kun havde et meget lille økonomisk overskud til at deltage i sociale forsikringsordninger. I dag betaler arbejderne nemlig omkring $90 \%$ af de offentlige indtægter og dermed også i al væsentlighed deres egen arbejdsløshedsunderstøttelse.

Kombineres de negative erfaringer vedrørende kontrol, optagelses- og udbetalingsregler m.v. med den helt ændrede skatte- og finansieringssituation og yderligere med de meget høje organisationsprocenter, er det politisk aktuelt, at arbejderklassen og de underordnede mellemlag nu rejser kravet om afløsning af statsliggørelsen med en selvorganisering, selvforvaltning og selvfinansiering af arbejdsløshedssystemet.

\section{Statslig kontrol og selvorganisering}

P.J. afviser den problematisering af velfærdspolitikken, som bl.a. tematiseres af undertegnede. Afvisningen begrundes i, at der ikke findes noget alternativ til velfærdspolitikken i den aktuelle situation, og at udviklingen i velfærdspolitikken har medført en række fordele for arbejderklassen i forhold til en tidligere periode, hvor det sociale sikkerhedssystem ikke fandtes.

Heroverfor står kritikken af velfærdsstatspolitikken. Den fremhæver den sårbarhed, som arbejderklassen i dag er underlagt ved ikke at have erfaringer for selvorganisering og tradition for at bearbejde egne erfaringer som bolværk imod nedskæring og ændring i betingelserne for sikkerhedssystemet og for modtagelse af forskellige former for ydelser. Udviklingen af velfærdspolitikken har medført en række fordele, som rigtigt fremhævet af P.J., men er funderet på politikken i det borgerlige demokratiske system og lige præcis så sårbart som svingningerne $\mathrm{i}$ politikudviklingen medfører. Når vi mener, at arbejderbevægelsen er fanget i noget af en blindgyde, så er det fordi selvorganise- 
ringspotentialet er fjernet samtidig med, at der ingen garanti er for at det folketingspolitiske grundlag til stadighed er tilstede for at opretholde det sociale sikkerhedsssystem. Det lader sig ikke gøre fra den ene dag til den anden at fjerne hele velfærdskomplekset - men udviklingen har været $\mathrm{i}$ gang siden sidst i 1970'erne.

Når vi påpeger nødvendigheden af at diskutere alternative strategier i forhold til velfærdsstatens eventuelle genopretning, så er det, fordi vi mener, at arbejderklassens kamppotentiale på denne måde kan forøges.

P.J. tillægger os den opfattelse, at selvorganiseringen er vejen til socialisme. $\mathrm{Vi}$ mener, selvorganiseringsstrategien først og fremmest er et forslag til opg $\varnothing \mathrm{r}$ med staten. I den historiske omtale af velfærdsstatens udvikling og bedrifter $\mathrm{i}$ arbejderklassens interesse, ser P.J. helt systematisk bort fra alle de fornedrende og undertrykkende indgreb, som også er blevet gennemført af staten.

Men selvorganiseringsstrategien er også et forslag til at indlede diskussion af, hvordan det borgerlige demokratiske system virker ind på fagbevægelsens organisatoriske forhold med repræsentationsdemokrati og en kommunikations- og magtstruktur, som bedst kan karakteriseres som en borgerlig offentlighedsform. En offentlighedsform, hvor oppositionsmeninger forsvinder i det centralistiske system, og hvor organisationsformen betyder mere end sagens indhold.

Selvorganisering og socialisme hænger tæt sammen: ingen socialisme uden selvorganisering. Men i den aktuelle debat skal begrebet selvorganisering ikke kun opfattes som en parole for vejen til socialisme. Selvorganiseringsstrate- gien er først og fremmest et redskab til at dæmme op imod den statslige kontrol med de sociale ydelser, som arbejderklassen via skatter og afgifter selv betaler. Det er som nævnt arbejderklassens og mellemlagenes egne penge, der igennem det offentlige system anvendes til en omfordeling indenfor klassens egne rækker.

Hensigten med denne problematisering af velfærdsstaten er selvfølgelig ikke, at dagpengesystemet skal afskaffes, men at den statslige magtudøvelse og kontrolmulighed skal fjernes, ved at selvfinansiering, organisering og kontrol af systemet skal formidles igennem en alternativ institution, der ikke er påvirket af statens interventioner.

\section{Kan staten harmonisere interessemodsætningerne $\mathbf{i}$ arbejderklassen?}

P.J. nævner rigtigt, at 1907-loven bevirkede en statslig homogenisering af arbejderklassens interesser derved, at de dårligst stillede lag nu fik økonomisk mulighed for at oprette en Akasse. Men det er væsentligt samtidig at gøre opmærksom på, at hermed er det også stort set slut med socialpolitikkens homogeniserende effekter. Som det for danske forhold er dokumenteret hos Iver Hornemann Møller (1981), for Sveriges vedkommende hos Marklund (1975), og vedrørende England hos Kincaid (1979) harmoniserer socialpolitikken ikke, men cementerer i stedet de klassekampbestemte lønninger for arbejdskraften gennem en tilsvarende lovgivningsmæssig differentiering af ydelser, tildelingsregler m.v. Det betyder, at socialpolitikkens homogeniserende effekt $\mathrm{i}$ dag $\mathrm{i}$ bedste fald alene vedrører individer og lags 
horisontale indkomstfordeling. (Persson 1980).

P.J. giver udtryk for, at staten kan harmonisere interessemodsætningerne i arbejderklassen, og at staten faktisk er den eneste instans, der er i stand til at gøre det. På den måde udråber P.J. et hurra for staten og udnævner den til arbejdersolidaritetens formidler.

P.J. har ret i, at det såkaldte arbejderaristokrati - med god beskæftigelse og rimelig $1 \varnothing \mathrm{n}-$ har haft muligheder for at sikre sig imod arbejdsløsheden. Deres beskæftigelsesmuligheder har været gode, og de har haft en indtjeneing, som gjorde det muligt at finansiere en forsikringsordning. Sådan har situationen ikke været for hele klassen, og den fagopdelte organisering har medført, at store grupper ikke havde $\varnothing$ konomisk overskud til at lave forsikringsordninger.

P.J. påpeger, at denne differentiering medfører interessemodsætninger indenfor klassen, hvilket gør det umuligt at organisere et dagpengesystem for klassen selv. Hvad klassen ikke selv kan, kan staten til gengæld. Det er her, staten træder til som den eneste instans, der kan forene interessemodsætningerne og indføre et dagpengesystem, der er i klassens interesse som helhed, mener P.J.

Hans argumentation medfører; at statens indblanding opløser modsætningerne imellem arbejderklassens forskellige dele, f.eks. imellem faglærte og ufaglærte. Differentiering i interesserne for arbejdsløshedsforsikring ændres imidlertid ikke af den offentlige organisering. Men differentieringen retter sig nu imod staten og folketingets politik i stedet for imod fagbevægelsen. Det vil sige at modsætningerne har ikke nogen mulighed for at blive forarbejdet eller forhandlet indenfor klassen. Derfor er de offentlige interventioner snarere en hindring for solidaritetens udvikling end en garant derfor. Den statslige politik udtrykkes blandt andet i Folketingets politiske bravalla slag, og de politiske beslutninger er altid kompromisser imellem forskellige klasser og politiske grupperinger, og resultatet bærer nødvendigvis præg af, hvilke interventionsformer, der har kunnet opnås flertal for.

Heroverfor står, at udvikling af solidaritet er en politisk bevægelse for sammenhold og egalitet, hvor der er differentieringer i eksistensgrundlaget og fremtidsudsigterne. Og de statslige politikker indenfor dagpengeområdet har som nævnt ikke harmoniseret modsætningerne, hvilket bl.a. er kommet til udtryk i en vis højredrejning blandt arbejderne med støtte til politiske partier, som kraftigt vil skære ned på det socialpolitiske område, f.eks. Det Konservative Folkeparti og Fremskridtspartiet.

Alle præmisserne vedrørende dagpenge er lagt i det offentlige regi udenfor arbejderbevægelsen, og ændringerne af betingelserne er et generelt politisk spørgsmål og ikke et spørgsmål om fagbevægelsens forhandlinger internt.

Det er afgørende at bide mærke i den forskydning af beslutningsgrundlaget og -indholdet, når man skal vurdere fordele og ulemper ved de offentlige interventioner. $\mathrm{P}$. J. har ret $\mathrm{i}$ at påpege, at fagbevægelsen også har sit eget kontrolsystem, og at man ikke kan forudsætte, at der her skulle være tale om en mere liberal holdning. Men grundlaget for en intern fagbevægelseskontrol er under alle omstændigheder mere specifikt placeret $\mathrm{i}$ arbejdernes situation end den kontrol og registrering, der er placeret i den centrale statsadministration. 


\section{Hvor blev reformisme- kritikken af?}

P.J.'s hensigt med kommentarerne er at bringe reformismekritikken ned på jorden. I P.J.'s positive fremstilling af statens funktioner, hvorigennem bl.a. de klasseinterne interessemodsætninger harmoniseres, ses helt bort fra de klassemodsætninger, som staten er formidler af, som en samling apparater domineret af de borgerlige klassekræfter. Det diskuteres heller ikke, hvilke muligheder og hvilke begrænsninger, som arbejderklassen har stået overfor, og står overfor, når det drejer sig om at påvirke de offentlige interventioner.
P.J. har en evne til at læse den politiske historie ovenfra, dvs. ud fra de politiske resultater. Og ikke nedefra, dvs. ud fra de kampe, der er foregået, og som er blevet nedkæmpet af kapitalfraktionerne, småborgerskab, LOtoppen og et parlamentarisk flertal, der ikke giver plads til de minoriteter, som er nederst på stigen, og som er fjernet fra den historie, der kun handler om de politiske resultater. Det er bemærkelsesværdigt, at hele oppositionen i fagbevægelsen hvoraf der har været mange fraktioner, hvor ikke mindst syndikalisterne skal trækkes frem som eksempel - er en død hund i P.J.'s fremstilling.

Note:

J.C. Kincaid: Poverty and equality in Britain: Harmondsworth.

Stefan Marklund: Fattigdom och socialpolitik i Vilhelmina. Umeå 1975.

Iver Hornemann Møller: Klassekamp og sociallovgivning, København 1981.

Gunnar Persson: Til socialpolitikkens försvar. Zenit. nr. 65, maj-juni 1980. 